\title{
Associated Construction and Engineering Co. of California $v$. Workers' Compensation Appeals Board: Comparative Negligence in the Workers' Compensation System
}

An assembly line worker loses the use of three fingers in an accident at work. It is subsequently determined that the manufacturer was negligent in designing the machine the employee was operating, that the employee was negligent in operating the machine, and that the employer was negligent in failing to provide sufficient lighting in the work area. All three factors contributed to the accident.

In Associated Construction and Engineering Co. of California v. Workers' Compensation Appeals Board, ${ }^{1}$ the California Supreme Court addressed the extent to which an employer who is concurrently neghgent with a third party tortfeasor can reduce its workers' compensation liability to the injured einployee by the latter's damage recovery froin the third party. The court held that such an employer is entitled to the application of comparative negligence principles ${ }^{2}$ to a credit ${ }^{3}$ or reimbursement ${ }^{4}$ determination. In addition, it determmed that, in the absence of a prior judicial determination, the Workers Compensation Appeals Board (WCAB) should determine the degree of the employer's comparative fault. Under this framework, the employer ${ }^{5}$ is entitled to a credit for the amount by which its compensation hability exceeded its proportional share of the injured employee's recovery.

The application of comparative negligence principles to an employer's right to offset workers' compensation hability after employee recovery from a third party constitutes a significant departure from prior judicial interpretations of the relevant Cahfornia workers' com-

1. 22 Cal. 3d 829, 587 P.2d 684, 150 Cal. Rptr. 888 (1978) (Mosk, J.) (4-3 decision).

2. See Li v. Yellow Cab Co., 13 Cal. 3d 804, 532 P.2d 1226, 119 Cal. Rptr. 858 (1975).

3. Cal. LaB. Code $\$ 3861$ (West 1971).

4. Id. $\S 3856(\mathrm{~b})$.

5. In California, the definition of an "employer" includes the employer's workers' compensation insurer. CAL. LAB. CODE $\$ 3850$ (West 1971). Therefore, the compensation carrier has the same right of action as the insured employer because it is subrogated to the employer's rights. Hereinafter, "employer" will be used to mean either the actual employer or his coinpensation insurer. 
pensation statutes. $^{6}$ The California Supreme Court, in two leading workers' compensation cases, had previously limited the apphicability of the reimbursement and credit statutes to nonnegligent employers, although the statutes themselves contain no such facial limitation.

In Witt $v$. Jackson, ${ }^{7}$ the court had held that statutory changes ${ }^{8}$ had supplanted the rule allowing reimbursement to neghigent employers. ${ }^{9}$ The court concluded, on the basis of its reading of the California Civil Code, that to allow a neghigent employer reimbursement would allow it to profit from its own wrong. ${ }^{10}$ Espousing the principle agamst double recovery, the court reduced the damages to be paid by the third party by the amount of workers' compensation benefits the employee had received. ${ }^{11}$ Subsequently, in Roe v. WCAB, ${ }^{12}$ the court permitted employee double recovery rather than grant a neghigent employer a credit against future workers' compensation benefits. ${ }^{13}$

In the afternath of Witt and Roe, the timing of the third party tort

6. Workers' compensation benefits are the exclusive remedy against employers available to employees injured in the course of their einployment. CAL. LAB. CODE $\$ 3601$ (West Supp. 1979). They are determined without regard to the fault of any party. CAL. CoNST. art. XIV, $\$ 4$. Regardless of the workers' coinpensation benefits received, an employee is free to bring actions against third party tortfeasors who proximately caused the injuries at issue. See CAL. LAB. CODE $\$ 3852$ (West 1971).

7. 57 CaI. 2d 57, 366 P.2d 64I, 17 Cal. Rptr. 369 (1961).

8. Prior to 1957 , an employer could seek reimbursement from third party tortfeasors for the amormt paid in benefits to the injured employee until the time of trial. The fact that the employer was concurrently negligent was irrelevant. See Finnegan v. Royal Realty Co., 35 Cal. 2d 409, 43435, 218 P.2d 17, 33 (1950). In 1957, the Code of Civil Procedure was amended to provide for contribution between joint judgment tortfeasors. CAL. CIV. PROC. CODE $\$$ 876(a) (West Supp. 1979).

9. $57 \mathrm{Cal} .2 \mathrm{~d}$ at 70,366 P.2d at 648,17 Cal. Rptr. at 376.

10. Id. at 72, 366 P.2d at 649, 17 Cal. Rptr. at 377 (citing CAL. Clv. Code $\S 3517$ (West 1970)). This view differs from that of most other states that have eonsidered the question. See, e.g., General Elec. Co. v. Cuban Am. Nickel Co., 396 F.2d 89 (5th Cir. 1968) (Louisiana); Sargent v. Axel H. Ohman, Inc., 343 F. Supp. 316 (D. Minn. 1972); Perruccio v. Nadeau, 30 Conn. Supp. 126, 304 A.2d 225 (Super. Ct. 1973); Pyles v. Bridges, 283 So. $2 d 394$ (Fla. Dist. Ct. App. 1973); Galvan v. John Caretti Co., 6 Ill. App. 3d 894, 287 N.E.2d 90 (1972); Fidehity \& Cas. Co. v. Cedar Valley Elec. Co., 187 Iowa 1014, 174 N.W. 709 (1919); General Box Co. v. Missouri Util. Co., 331 Mo. 845, 55 S.W.2d 442 (1932); Einployers Mut. Liab. Ins. Co. v. Mueller, 273 Wis. 616, 79 N.W.2d 246 (1956).

11. 57 Cal. $2 \mathrm{~d}$ at 73,366 P.2d at 650 , 17 Cal. Rptr. at 378.

12. 12 Cal. 3d 884, 528 P.2d 771, 117 Cal. Rptr. 683 (1974). The companion case to Roe is Gregory v. WCAB, 12 Cal. 3d 899, 528 P.2d 782, 117 Cal. Rptr. 694 (1974).

13. Roe v. $W C A B$ rejected the idea that the einployee should not be allowed a double recov. ery. This decision was based on three principles. First, the policy against double recovery espoused in Witt was said to protect primarily the third party tortfeasor, not the employer. $12 \mathrm{Cal}$. 3d at 889, 528 P.2d at 775, 117 Cal. Rptr. at 687. Second, the Labor Code subrogation provisions were said to be no authority for granting credit to a negligent employer. Id. at $890,528 \mathrm{P.2 \textrm {d }}$ at 775-76, 117 Cal. Rptr. at 687-88. These provisions provide that

After payment of litigation expenses and attorneys' fees fixed by the court pursuant to Section 3856 and payment of the employer's lien, the einployer shall be relieved from the obligation to pay further compensation to or on behalf of the employee under this division up to the entire amoimt of the balance of the judgment, if satisfied, without any 
action dictated the distribution of the windfall. ${ }^{14}$ Under this approach, an arbitrary time factor, easily mampulated by the employee, governed this component of the compensation system. Accordingly, the third party was the beneficiary of money paid by the employer prior to judgment, while the already fully compensated employee reaped additional benefits from ainounts subsequently due.

With the advent of the comparative negligence regime in $\mathrm{Liv}$. Yellow Cab Co. ${ }^{15}$ however, the prospects for einployer offset rights in workers' compensation cases were dramatically enhanced. In the evolution of comparative indemnity principles from $L i$ to American Motorcycle Association v. Superior Court ${ }^{16}$ and, finally, Safeway Stores, Inc. ${ }^{2}$. Nest-Kart, ${ }^{17}$ the assessment of liability in proportion to fault became a prominent feature of California tort law. Associated Construction marks the introduction of this principle into the California law of workers' compensation.

This Note will argue that comparative negligence principles should not be applied to the workers' compensation system. Part I sets forth the facts of the case and the court's opinion. Part II analyzes botl the decision and the unaddressed issue of the role of employee negli-

deduction. No satisfaction of such judgment in whole or in part, shall be valid without giving the employer notice and a reasonable opportunity to perfect and satisfy his lien.

CAL. LAB. CODE $\$ 3858$ (West 1971). In addition, the statute provides:

The appeals board is empowered to and shall allow, as a credit to the employer to be applied agaimst his liability for coinpeusation, such amount of any recovery by the employee for his mjury, either by settlement or after judgment, as has not theretofore been applied to the payment of expenses or attorneys' fees, pursuant to the provisions of Sections 3856,3858 , and 3860 of this code, or has not been applied to reimburse the employer.

Id. $\$ 3861$. Third, the court decided that the WCAB has authority to decide the issue of employer negligence. 12 Cal. $3 \mathrm{~d}$ at $892,528 \mathrm{P} .2 \mathrm{~d}$ at $777,117 \mathrm{Cal}$. Rptr. at 689.

14. A windfall results because the employer and the third party are each separately liable to the employee for the same mjury. The employer is liable under the workers' compensation statute and the third party is fully liable in tort. Consequently, they are jointly liable for more than $100 \%$ of the damages. Some party or parties must benefit from this excess liability.

15. In the landmark decision of Li v. Yellow Cab Co., 13 Cal. 3d 804, 532 P.2d 1226, 119 Cal. Rptr. 858 (1975), the California Supreme Court replaced the rule of contributory negligence with comparative uegligence, which assesses liability in proportion to fault. The purpose of this shift in policy was to further equity by "assigu[ing] responsibility and liability for damage in direct proportion to the amount of negligence of each of the parties." Id. at 829, 532 P.2d at 1243, 119 Cal. Rptr. at 875 .

16. In American Motorcycle, 20 Cal. 3d 578, 578 P.2d 899, 146 Cal. Rptr. 182 (1978), the court faced the question of how to divide a loss between a negligeut plaintiff and multiple negligent tortfeasors. The court retained the doctrine of joint and several hability, but modified the common law indemnity doctrine, which traditionally was concerned with shifting the entire loss from one tortfeasor to another. Partial indemnity aunong concurrent tortfeasors was permitted on a comparative fault basis. This change, according to the court, furthered the equitable distribution of loss between two or more tortfeasors. Id. at 584, 578 P.2d at 902, 146 Cal. Rptr. at 185 .

17. 21 Cal. 3d 322, 579 P.2d 441, 146 Cal. Rptr. 550 (1978). Apportionment betweeu a negligent and a strictly liable tortfeasor was permitted on a comparative fault basis. 
gence. Part III presents an alternative resolution of the problems exacerbated by the Associated Construction decision.

\section{THE OPINION}

\section{A. Summary of the Case}

In the course of his employment as a carpenter for Associated Construction \& Engineering Coinpany, Jeffrey Cole injured his right ankle. At the time, his employer was insured with California Coinpensation and Fire Company. Cole received both workers' compensation benefits for temporary disability ${ }^{18}$ and the necessary medical treatment. Subsequently, he recovered $\$ 40,000$ in the settlement of his $\$ 60,000$ suit agamst a third party, Napp Systems, U.S.A., Inc. ${ }^{19}$

Shortly thereafter, Cole sought a perinanent disability award. The workers' coinpensation judge found that he was $29 \%$ permanently disabled and therefore entitled to a total monetary award of $\$ 8,087$, of which $\$ 2,270$ had already been advanced by his einployer. ${ }^{20}$ The employer, invoking comparative negligence principles, claimed a credit against its liability in the annount of the employee's net recovery against Napp. ${ }^{21}$ Relying on Roe v. $W C A B,{ }^{22}$ Cole pleaded the einployer's concurrent negligence as a bar to any credit. The trial court found the employer neghigent, concluding that the $L i$ doctrine did not affect the Roe rule. This judginent was affirned by the Workers' Compensation Appeals Board, and the employer appealed.

The California Supreme Court, in modifying Roe, held that coinparative negligence principles should be applied when an injured einployee recovers froin a third party tortfeasor. It therefore determined that a concurrently negligent einployer unust be allowed a credit or reimbursement for the annount by which its workers' compensation liability exceeds its proportional share of liability. ${ }^{23}$

18. An employee injured in the course and scope of his employment can recover workers' compensation benefits from his employer. CAL. LAB. Code $\$ 3600$ (West Supp. 1979). In California, there are two types of workers' compensation benefits, temporary and permanent. The former are awarded by the employer right after the injury. Later, an enployee inay appear before the WCAB and request a permanent disability award.

19. The record reveals neither the basis of that suit, nor whether the employer sought a lien against the settlement to recoup his prior workers' compensation expenditures. In addition, it does not indicate whether the employer joined or intervened in the suit, or if the action was settled without his consent.

20. 22 Cal. 3d at 835,587 P.2d at 687,150 Cal. Rptr. at 891 .

21. The employer advanced its claim for $\$ 40,000$ under Labor Code $\S 3861$.

22. 12 Cal. 3d 884, 528 P.2d 771, 117 Cal. Rptr. 683 (1974).

23. 22 Cal. 3d at 842,587 P.2d at $692,150 \mathrm{Cal}$ Rptr. at 896. 


\section{B. The Court's Analysis}

To support its assessment of the applicability of comparative fault principles in this context, the court first examined the relevant sections of the California Labor Code. Under sections $3859(\mathrm{~b})^{24}$ and 3860(b), ${ }^{25}$ an employer is denied its former riglit to veto an injured employee's settlement of a claim against a third party. In addition, these sections provide that the employer may thereafter proceed with its claim against the third party. Section $3861^{26}$ specifically allows a credit to be applied against a settleinent. According to Justice Mosk, writing for the court, the disallowance of a credit claim in this situation would effectively deny nonnegligent employers the opportunity to recoup a substantial portion of the workers' compensation payinents which they would otlerwise receive as settlement credits. ${ }^{27}$ Accordingly, he concluded that the Cahfornia Legislature did not intend to insulate from einployer credit claims independent settleinents between employees and third parties. ${ }^{28}$

In determining the applicable principles in the adjudication of such credit claims, Justice Mosk noted that the saine considerations of "logic, practical experience and fundamental justice" 29 that motivated the $L i$ decision require the application of comparative principles to the Witt-Roe doctrine. Such application, he argued, is consistent with the purposes of those rules and does not introduce fault into the workers' compensation systein in an unconstitutional manner. ${ }^{30}$

The Witt decision, permitting third parties to reduce their liability by the amount of the workers' compensation benefits paid to the injured employee, reflected a desire to distribute hability equitably between the liable parties. ${ }^{31}$ It was intended to approximate the result in cases decided under the general statutory rule that allowed contribu-

24. Cal. Lab. CoDE $§ 3859$ (b) (West Supp. 1979) reads as follows:

Notwithstanding anything to the contrary contained in this chapter, an employee may settle and release any claim he may have agamst a third party without consent of the employer. Such settlement or release shall be subject to the employer's right to proceed to recover compensation he has paid in accordance with Section 3852.

25. CAL. LAB. CODE $\$ 3860$ (b) (West Supp. 1979) reads in full:

(b) Except as provided in Section 3859, the entire amount of such settlement, with or without suit, is subject to the employer's full claim for reimbursement for compensation he has paid or become obligated to pay and any special damages to which he may be entitled under Section 3852, together with expenses and attorney fees, if any, subject to the limitations in this section set forth.

26. See note 13 supra.

27. 22 Cal. 3d at $839-40,587$ P.2d at 690,150 Cal. Rptr. at 894.

28. Id. at 840,587 P.2d at 690,150 Cal. Rptr. at 894 .

29. Id., 587 P.2d at 691,150 Cal. Rptr. at 895 (quoting $L i, 13$ Cal. $3 \mathrm{~d}$ at 808,532 P.2d at 1229, 119 Cal. Rptr. at 861).

30. Id. at 844,587 P.2d at 693,150 Cal. Rptr. at 897 .

31. Id. at 841,587 P.2d at 691,150 Cal. Rptr. at 895 . 
tion between joint tortfeasors. ${ }^{32}$ The Associated Construction court accordingly concluded that under the Witt doctrine, "to the extent allowed by the employer's statutory liability, the employer and third party should share liability as would ordinary concurrent tortfeasors." ${ }^{33}$ To the extent that an employer avoids its duty of contribution, the court reasoned, it was profiting from its own wrong. Without further explanation, Justice Mosk applied the same logic to the credit provisions of the Cahfornia Labor Code interpreted in Roe. ${ }^{34}$

The court proceeded to the conclusion that since comparative indemnity between inultiple tortfeasors has been approved, ${ }^{35}$ the conceptual basis for the Witt and Roe rules had been undermined. Hence, under the modern regime a concurrently negligent employer should receive credit or reimbursement for the amount by which its workers' compensation hability exceeds its proportional share of the injured enployee's recovery. ${ }^{36}$

Fimally, the court held that the third party tortfeasor should be allowed, as in Witt, to plead employer negligence. The trier of fact should first determine the einployer's percentage of fault according to the principles of American Motorcycle. The court should then deduct the employer's percentage share of the employee's total recovery from the third party's liability. This deduction, of course, would be limited to the amount of workers' compensation benefits assessed against the employer. The einployer would thereby be denied any reimburseinent or lien to the extent the percentage of its contribution is less than the percentage of its fault.

Moreover, when the issue of the employer's negligence arises in a credit claim situation based on a third party settlement, the WCAB should determine the total damages to which the einployee is entitled and the percentage fault of the employer. It should subsequently deny the employer any credit until the ratio of its contribution corresponds to its proportional share of fault. Thereafter, the employer should receive a credit for the full amount available under Labor Code section $3861 .{ }^{37}$

The WCAB's authority to make the necessary factual determinations presented an important constitutional question. ${ }^{38}$ The court had already held in Roe that the WCAB's determmation of the employer's

32. Cal. Civ. Proc. Code $\S \S 875-880$ (West 1970).

33. 22 Cal. 3d at 841,587 P.2d at 691,150 Cal. Rptr. at 895.

34. Id.

35. American Motorcycle Ass'n v. Superior Court, 20 Cal. 3d 578, 578 P.2d 899, 146 Cal. Rptr. 182 (1978).

36. 22 Cal. 3d at 842,587 P.2d at 692,150 Cal. Rptr. at 896.

37. Id. at $843,587 \mathrm{P} .2 \mathrm{~d}$ at $692,150 \mathrm{Cal}$. Rptr. at 896 .

38. Id. at 844,587 P.2d at 693,150 Cal. Rptr. at 897 . 
fault did not contravene the constitutional requirement that the workers' compensation system compensate workers "irrespective of the fault of any party." ${ }^{39}$ In Associated Construction, the court conceded that the application of comparative principles to employer credit rights might burden Board proceedings to some extent. The court maintained, however, that this inquiry would not contravene the constitutional purpose of accomplishing "substantial justice in all cases expeditiously, inexpensively, and without encumbrance of any character." 40

In dissent, Justice Jefferson ${ }^{41}$ charged that the 1971 amendments to Labor Code sections 3859 and 3860 preclude any allowance of a credit for an employee's recovery from a third party tortfeasor in an out of court settlement. ${ }^{42} \mathrm{He}$ also concluded that the introduction of fault into the workers' compensation system under comparative negligence principles would violate the California Constitution ${ }^{43}$ and would encumber the inexpensive and expeditious accomplishinent of substantial justice. ${ }^{44}$

\section{II}

\section{Comparative Fault IN THE Workers' Compensation SYSTEM}

The court's decision in Associated Construction is premised upon the assumption that, absent a statutory or constitutional prohibition, the same considerations of "logic, practical experience, and fundamental justice" that justify the application of comparative negligence principles to other tort cases also justify their introduction into the workers' compensation system. This extension is inappropriate, smce the practical problems of applying comparative negligence principles to the workers' compensation system outweigh any mcremental increase in "fundamental justice" that might result. Moreover, in Associated Construction, the court failed to distinguisli the precedential import of the two central decisions upon which it relies. It also neglected to assess the potential impact of its decision on the employer's right not to join an employee's suit. Finally, the role of employee negligence is inadequately addressed in Associated Construction. These lapses constitute the major pitfalls in the court's decision.

\footnotetext{
39. 12 Cal. 3d at 891,528 P.2d at 776,117 Cal. Rptr. at 688. See CAL. Const. art. XIV, $\S 4$.

40. 22 Cal. $3 \mathrm{~d}$ at 845,587 P.2d at 693,150 Cal. Rptr. at 897 (citing CAL. Const. art. XIV, §4).

41. Justice Jefferson of the California Court of Appeal for the Second District, sitting by assigninent of the Judicial Council, was joined in dissent by Chief Justice Bird and Justice Tobriner.

42. 22 Cal. $3 d$ at 849,587 P.2d at 696,150 Cal. Rptr. at 900.

43. CAL. Const. art. XIV, $\S 4$.

44. 22 Cal. $3 \mathrm{~d}$ at $852-61,587$ P.2d at 698-704, 150 Cal. Rptr. at 902-08.
} 


\section{A. Reimbursement vs. Credit}

The Associated Construction court confused the relevant precedent in its analysis of concurrent tortfeasor liability. While Witt was a reimbursement case, Roe, like Associated Construction, imvolved a credit clain. Justice Mosk, recalling that the purpose in Witt was to equitably distribute liability between the negligent employer and the third party tortfeasor, reasoned that it would not be inconsistent with the purpose to apply those principles to the credit situation. Ignoring the Roe analysis of credit clains, Justice Mosk cited Witt for the proposition that to the extent allowed by the employer's statutory liability, the employer and third party should share liability as would ordinary concurrent tortfeasors. $^{45}$

The Associated Construction court determined that avoiding contribution under the reimburseinent provisions allows employers to profit froin their own wrong. Then, witlout furtler explanation, the court stated that the saine logic applies to the credit provisions of the California Labor Code, as interpreted in Roe. ${ }^{46}$ The decision in Roe, however, did not involve the allocation of hability between concurrently negligent parties. ${ }^{47}$ Rather, it involved allocation between an already fully coinpensated innocent employee and a negligent employer-a situation dissimilar from that involving concurrent tortfeasors.

On its face, it seems logical to apply the sanne rules, as the court did in Associated Construction, to the reimbursement and credit situations. A uniform rule, lowever, has an unintended and undesirable effect in practice. Since in the reimburseinent situation all parties are before the court, the allocation is between the third party tortfeasor and the employer. In the credit situation, however, which is adjudicated before an adininistrative body (the WCAB) and not a court, the allocation is between the einployer and the injured einployee. Requiring the WCAB to determine the degree of fault of the various parties and the total damages to which an einployee is entitled creates additional costs and related diseconomies for an adinmistratively overburdened workers' compensation system.

\section{B. The Effect on Workers' Compensation System}

The decision in Associated Construction will increase the number of subrogation recoveries in workers' compensation litigation. Em-

45. Id. at 842,587 P.2d at 691,150 Cal. Rptr. at 895 .

46. Id. at 841,587 P.2d at 691,150 Cal. Rptr. at 895 .

47. For a thorough discussion of the analysis and theory underlying Roe, see Comment, Roe v. Workman's Compensation Appeals Board: Something Fishy in California Workers' Compensation Law, 27 HASTINGS L.J. 637 (1976). 
ployer negligence will no longer totally defeat subrogation riglits. In the aftermath of Associated Construction an employer may now obtam reimbursement or credit for any amount by which the ratio of its contribution would otherwise exceed its proportional share of fault.

A crucial consideration is the relative savmgs and costs to employers engendered by this rule. Under the facts of Associated Construction, for example, the employee was entitled to a permanent disability award of $\$ 8,085$ less $\$ 2,270$ advanced by the employer, leaving a balance of $\$ 5,815$. The gross settlement was $\$ 60,000 .{ }^{48}$ On the reasonable assumption that the gross settlement is at least not significantly lower than total damages, if the employer in the above example was less than $10 \%$ responsible, it would be ineligible for any credit. Because of the low compensation ceilings in the workers' compensation systein, tort damages will usually exceed statutory compensation. If this difference is frequently great, then employers will save little but will be obligated to bear higher administrative expenses. ${ }^{49}$ A comparative negligence determination undoubtedly will increase the cost of Board proceedings, simce wide-rangmg evidentiary presentations will be required.

The apphication of comparative primciples to the Associated Construction situation may therefore result in a net loss for employers. Even if it saves individual einployers money in isolated cases by allowing a credit where none would have previously been allowed, the aggregate suin of inoney recovered to the systein may be less than the increase in administrative costs. ${ }^{50}$

These potentially adverse effects upon employers are not the sole considerations. Indeed, in analyzing effects on the workers' coinpensation system, the employees' interest should be primary. To the extent that $R o e$ permitted double recoveries for employees, it might appear to liave benefited them greatly. This is not necessarily so, however, because the money expended for double recoveries could otherwise have been applied toward uniformly higher benefits. If application of the

48. 22 Cal. 3d at 858,587 P. 2 d at 702,150 Cal. Rptr. at 906.

49. Compensation rates are set by the insurance commissioner through the California Inspection Rating Bureau. To set compensation rates, the total actual accident cost of an industry is accumulated and reported every year. Subrogation recoveries become part of the funds available for the payment of losses. Rates are set each year by taking an amount equal to the total estimated accident cost of the industry for the following year, based upon the experience of the preceding two years, and adding a uniform adininistrative expense factor. Total accident cost for the industry includes a reduction for subrogation recoveries, which must be reported. Gross premiums are then set high enough to cover accident losses and administrative expense. See Lasky, Subrogation Under the California Workmen's Compensation Laws, 12 SANTA CLARA Law. 1, 5 (1972).

50. While potential individual recoveries inay be high enough to warrant the additional litigation costs for the individual einployer, all einployers will collectively bear the increased administrative expenses. 
rule of Associated Construction generates more money in subrogation recoveries than it requires to be expended in administrative costs, the system will benefit employees collectively even though it will reduce some individual double recoveries. If, however, the application of coinparative principles costs the system more than it recovers, it will hurt employees and employers both individually and collectively. Employers will pay higher premiums, and the demands of employee groups for higher benefits ${ }^{51}$ will receive less sympathy since any increases would only further escalate premiums already raised to cover higher adinimistrative costs.

The apphication of coinparative principles to the Witt situationreimburseinent claims in civil court-does not impose the same costs on the workers' compensation systein. The application of comparative principles in that situation could only increase the net revenue of the workers' compensation system. Subrogation recoveries won by employers would enrich the systein without adding any additional administrative costs.

The application of comparative principles sliould likewise be less burdensome in the credit situation following a judgment. In that case, there is already a court-deternined amount of damages and an allocation of fault. The WCAB could then proceed witl the inexpensive process of mechanically applying those same figures to determine how much credit, if any, an employer is to receive.

\section{Impact on an Employer's Right not to Join an Employee's Suit}

Section 3856(b) of the Labor Code ${ }^{52}$ establishes the right of an employer not to join an einployee's suit against third-party tortfeasors. Simce, in the afterunatl of Witt and Roe, tliere is an increased likelihood that a third party will raise the defense of employer neghigence, this provision has been effectively neutralized. The employer will feel coinpelled to join since neither the third party nor the employee will have anything to lose and both much to gain from a finding of employer negligence. ${ }^{53}$ The rule announced in Associated Construction does nothing to alleviate this problem.

The Roe decision left open the question of the effect on a subsequent WCAB proceeding of a prior court finding of employer negligence or nonnegligence. The court in Associated Construction clearly implied that both the court finding of employer negligence and the degree thereof, if any, will be conclusive against botll the employee who

51. See 3 Cal. Workers' Comp. Rep. 146 (1975).

52. CAL. LAB. CODE \& 3856(b) (West 1971).

53. Comment, supra note 47 , at $668-69$. 
was a party in the original suit, and the einployer in the subsequent proceedings. The court stated:

When the issue of an employer's concurrent negligence arises in a judicial forum, application of comparative negligence principles is relatively straightforward. The third party tortfeasor should be allowed to plead the employer's negligence as a partial defense . . . . [T] he trier of fact should determine the employer's degree of fault . . . . Correspondingly, the employer should be denied any clain of reimbursement- or any lien under section 3856, subdivision (b)-to the extent that his contribution would then fall short of his percentage share of responsibility for the employee's total recovery. ${ }^{54}$

The employer, who has a statutory right not to join the suit, ${ }^{55}$ is therefore forced to join the suit to argue its lack of negligence under the Associated Construction approach. Since a finding by the court that he was negligent would determine not only that case but the WCAB outcoine as well, the einployer under Roe and Associated Construction is stripped of an important statutory protection.

\section{Role of Employee Negligence}

In Associated Construction, the court explicitly declined to address the question of the effect of einployee neghigence upon the proportional contribution of the einployer. ${ }^{56}$ Subsequently, in Aceves v. Regal Pale Brew Co.,$^{57}$ the court partially answered that question. It held that where the employee is negligent his recovery froin a third party tortfeasor should be coinputed by first subtracting froin the total award the proportionate ainount attributable to the einployee's negligence, and then subtracting the proportionate amount attributable to the ennployer's negligence up to the ainount of the workers' coinpensation benefits paid. ${ }^{58}$ Since in Aceves the einployer's percentage share of re-

54. 22 Cal. 3d at 842,587 P.2d at 691,150 Cal. Rptr. at 895 .

55. But see City of Sacramento v. Superior Court, 205 Cal. App. 2d 398, 23 Cal. Rptr. 43 (3d Dist. 1962) (employer can be made a necessary and indispensable party upon filing of a crosscomplaint by the third party, but only if the third party initially makes a satisfactory showing that a justiciable issue of employer negligence can be raised). Some procedural safeguards are provided. See also Carden v. Otto, 37 Cal. App. 3d 887, 897, 112 Cal. Rptr. 749, 755 (2d Dist. 1974), holding that a copy of all pleadings must be served on the employer, and that the einployer who chooses to intervene must be afforded a reasonable opportunity to be heard.

56. 22 Cal. $3 \mathrm{~d}$ at $843 \mathrm{n} .9,587$ P.2d at $692 \mathrm{n} .9,150 \mathrm{Cal}$. Rptr. at $896 \mathrm{n} .9$. Before an equitable means of distributing damages among the parties can be established, hability must be determined fairly. It is possible, for example, that the neghience of the employer may in fact be employee negligence attributed to the former under the doctrime of respondeat superior. This doctrime was invoked in the Witt decision, where the employer's only neghigence was that imputed to it as the employer of the negligent driver. 57 Cal. 2d at 62, 366 P.2d at 643, 17 Cal. Rptr. at 371 .

57. 24 Cal. 3d 502, 595 P.2d 619, 156 Cal. Rptr. 41 (1979).

58. This sum was to be limited by the amount of workers' compensation paid. For example, if the third party were $70 \%$ neghigent, the employee $5 \%$ negligent, and the employer $25 \%$ negligent, and the total award was $\$ 100,000$, the award would first be reduced by $\$ 5,000$ (5\% of $\$ 100,000)$, 
sponsibility for damages was greater than the compensation benefits paid, his claim for reimbursement was demed. The issue of credit rights was not raised.

This formulation circumvents a critical issue. Under the Aceves rule, no distinction is made between independent employer negligence and negligence imputed to the employer under respondeat superior. ${ }^{59}$ In this context, however, there is no reason to hold the employer liable for anything but independent negligence. When a negligent employee sues a third party, or when an employer asserts recovery rights, the employee's negligence should be attributed solely to him.

A system consistent with Aceves and Associated Construction would function in the following manner. The trier of fact would determine the percentage fault of the employee, the employer, and the third party. Total judgment for the employee would be first reduced by his percentage negligence, then allocated between the employer and the third party in accordance with the rule of Associated Construction. If the employee then sought workers' compensation benefits, the employer's further liability would be limited to its liability under Associated Construction, provided that the employee has received as much money from the sum of the judgment and the permanent disability benefits paid as he would have had he sought only workers' compensation benefits. Under this system, only mdependent employer negligence is considered employer fault. The employee receives, at a minimum, full workers' compensation benefits, and further benefits are then more accurately based on fault.

This rule for employee negligence provides an efficient approach consistent with the comparative negligence principles applied in Associated Construction. As completely as is possible in a hinited liability system, each party's liability is proportionate to its relative degree of fault in precipitating the injury. When the third party suit proceeds to judgment, the court will apportion hability in a fashion consistent with American Motorcycle ${ }^{60}$ and Safeway Stores. ${ }^{61}$ In contrast, the WCAB must make these determinations when the third party suit is settled. While this system offers a workable approach, it is suggested that a more equitable means of distributing damages would be available under a modified application of coinparative negligence principles enunciated im Associated Construction.

the proportional amount attributable to the employee's negligence, then subtracting the lesser of the workers' compensation benefits paid or $\$ 25,000(25 \%$ of $\$ 100,000)$. The remainder would be payable by the third party tortfeasor.

59. See generally W. Prosser, HANDBOOK OF THE LAW OF TORTS $\$ 80$ (4th ed. 1971).

60. 20 Cal. 3d 578, 578 P.2d 899, 146 Cal. Rptr. 182 (1978).

61. 21 Cal. 3d 322, 579 P.2d 411, 146 Cal. Rptr. 550 (1978). 
III

\section{Alternative Model}

Determination of the effect on recovery of employer negligence hinges on the underlying question of the proper allocation of windfall resultimg from multiple liability for the same mjury among employee, employer, and third party.

There is no reason in this context to distmguish between credit and reimbursement. Such a distinction is rooted in arbitrary time factors. The third party receives the benefit of workers' coinpensation payments made prior to judgment, while the employee receives the benefits of subsequent payments.

\section{A. Judicial Determinations}

Under the proposed system, the employee retains the right to bring a suit agamst the third party before full workers' compensation benefits have been determined. All parties-employer, einployee, and third parties-are made necessary and indispensable parties to the action. If the case proceeds to judgment, the trier of fact determines the percentage liabilities of all these parties-including that of the employeeunder the system already suggested. ${ }^{62}$ The employer files a lien for all benefits paid and to be paid. Total judgment is first reduced by the employee's percentage negligence. The remainder is allocated between the einployer and the third party, based on their respective percentage of fault. The third party is required, and the einployer allowed, to produce expert testimony predictimg the employee's perinanent disability ratimg, if any, on which his estimated future benefits would be based. The predicted ratimg would not bind the WCAB in any future proceeding to determine actual permanent disability.

The court would then reduce the employer's lien by the dollar amount corresponding to its percentage of fault. The employer's liability, however, is limited to the amount of its lien. The third party would then pay the greater of the difference between recovered damages and the amount of the lien or the difference between recovered damages and the employer's percentage share of imitial darnages. This would allow the third party to deduct from the judgment against it the amount by which the employer's lien had been reduced as a result of the employer's concurrent negligence. ${ }^{63}$

While this system may result in the third party or the employer

62. See text accompanying notes 56-58 supra.

63. A hypothetical fact situation illustrates this proposed solution. Assume that (1) the workers' compensation benefits paid and to be paid equal $\$ 1,000$; (2) the einployer filed a hen in the third party action for that amount; (3) the employee is found to be $25 \%$ responsible, the em- 
paying more or less than their proportionate share of the employee's total award, it nevertheless has several advantages. First, it is easy and relatively inexpensive to administer. This is a crucial factor in the context of the workers' compensation system where the level of benefits available to all employees depends on the cost of the system. Second, the employee receives all of the compensation to which he is entitled, but no double recovery. To the degree possible, each party is held hable in proportion to its own neghigence. Fimally, this proposal would eliminate the distimction between credit and reimbursement and the gamesmanship engendered by that distinction. ${ }^{64}$

\section{B. Settlements}

A further problem emerges when the third party suit is not determined by the courts but rather settled by the parties. In that situation the WCAB must either make the necessary factual determinations or foresake comparative principles for a less costly alternative.

The latter alternative is preferable. The employee's third party settlement should be subject to the employer's claim for reimbursement for compensation the employer has paid or become obligated to pay. There is no reason to treat credit rights any differently than reimbursement rights. The only question is whether the employer or the third party should benefit from the other's neghigence; since equity dictates neither result, it is contended that the suggested alternative approach would have numerous advantages.

First and foreinost, this proposal protects the employee interest in receiving adequate compensation for the injury from some source. All employees will benefit from a system that gives the employer the full benefit of the settlement. At any given level of premiums the level of benefits available to employees is a function of the administrative costs and "balance of payments" of the workers' compensation system. Hence, a rule which costs less to administer and allocates less money to employees to whom a third party is fully hable leaves more money for distribution to injured employees whose only source of benefits is workers' compensation.

ployer $25 \%$ responsible (independent of employee negligence), and the third party $50 \%$ responsible; and (4) the jury found total damages to be $\$ 12,000$.

Total damages are first reduced by $25 \%$ (the employee's percentage negligence) to $\$ 9,000$. The employer would be liable for $25 \%$ of $\$ 12,000$, or $\$ 3,000$, except for the fact that its liability is limited to the amount of its $\$ 1,000$ lien. The third party then pays the greater of the difference between recovered damages $(\$ 9,000)$ and the amount of the lien, or the difference between recovered damages and the employer's percentage share of the initial damages. In this instance the einployer's lien $(\$ 1,000)$ is less than its percentage share $(\$ 3,000)$, so the third party pays $\$ 8,000$. The employee receives $\$ 8,000$ and is free to seek his remaining disabihty benefits.

64. See Comment, supra note 47, at 669. 
Second, this proposal will continue to protect the related employee interest in a safe workplace. Any tendency toward more frequent negligent conduct on the part of einployers will be checked by tlieir mability to know in advance in any particular instance whether a third party will be concurrently liable for injuries or, for that matter, whether such a third party, if it exists, will be willing to settle the claim out of court.

Third, it will also protect the employer from disadvantageous settiements made witlout its consent. While employer consent will not be requircd, this interest will be advanced because tlie employer stands only to gain froin any settleinent.

Finally, the settlement rate should not be adversely affected. The rule should facilitate an increased average dollar annount of settlement. Settlements take into account the possibility of recovery froin another source, ${ }^{65}$ and both parties will now be cognizant of the fact that the employee cannot look to the einployer for furtlier benefits.

While this rule could theoretically result in the creation of a disincentive for third parties to settle, such a result is unlikely. The involved parties will undoubtedly be aware that if the case proceeds to judgment the employer will be liable for some of the damages and litigation costs; in contrast, if the case settles, the employer is relieved of liability. The employer will therefore liave a strong incentive to contribute to the settlement, thereby lowering the third party's settling cost. As a result, it will frequently be less costly for botll the employer and third party to join in a settlement. ${ }^{66}$ Adininistrative convenience and judicial economy are also served by handling the entire matter in one proceeding.

\section{CONCLUSION}

In Associated Construction, the California Supreme Court further extended the principles of comparative fault enunciated in $L i v$. Yellow $\mathrm{Cab} \mathrm{Co}$. This extension was attempted in spite of the inherent conflict between court-iniposed comparative principles and the statutory nofault workers' compensation systen, which is intended to give the injured worker "medical care needed as a result of his injury and a nodest but not full recompense for his lost earnings and his loss of earning capacity." ${ }^{\text {"7 }}$

The Associated Construction court failed to recognize that the use of comparative negligence principles in the administration of workers' conipensation imposes an unjustified financial burden on that system.

65. 22 Cal. $3 \mathrm{~d}$ at 834,587 P.2d at 686,150 Cal. Rptr. at 890 .

66. The significance of this problem depends on two sets of costs: the increased cost of settlement relative to the cost of trial, and the cost of the extra court trials that result from imconsistent application of the Associated Construction rule.

67. 22 Cal. 3d 862, 587 P.2d at 704, 150 Cal. Rptr. at 908. 
Additionally, the specific method of applying those principles enunciated in Associated Construction does not alleviate the preexisting problem created by the different treatment of the credit and reimbursement situations. Fimally, it substantially weakens the employer's right not to join the employee's suit against the third party tortfeasor.

For these reasons comparative negligence principles should not be imcorporated into the workers' compensation system. If, however, comparative neghigence principles are to apply to the employer's right to credit or reimbursement, the system adopted by the court should be modified in two ways. First, only independent negligence should be deemed employer neghigence. Second, the system should be amended to insure that the question of who receives the windfall is not determined by such an arbitrary factor as when the lawsuit is filed. In the aftermath of Associated Construction, these are necessary adjustments designed to assure the equitable and efficient functioning of California's workers' compensation system.

Rhonda J. Starr*

* B.A. 1973, University of California, Los Angeles; M.B.A. 1975, Graduate School of Management, University of California, Los Angeles: J.D. 1980, Boalt Hall School of Law, Univcrsity of California, Berkeley. 